\title{
KEBIJAKAN PEMERINTAH TENTANG PENYEDIAAN SARANA DAN PRASARANA OLAHRAGA PENDIDIKAN DI SMP NEGERI SE- KECAMATAN BAJAWA
}

\author{
Yanuarius Ricardus Natal \\ Dosen Pendidikan Jasmani Kesehatan dan Rekreasi, STKIP Citra Bakti \\ yanuariusrichardus@gmail.com
}

\begin{abstract}
Abstrak
Penelitian ini bertujuan untuk mendeskripsikan kebijakan pemerintah tentang penyediaan sarana dan prasarana olahraga pendidikan di SMP Se-Kecamatan Bajawa yang di tinjau dari aspek, ketersediaan serta ketercukupan. Penelitian ini dilakukan di SMP Negeri di wilayah Kecamatan Bajawa. Subjek dalam penelitian ini adalah kepala bidang SMP/MTs, kepala SMP Negeri di Kecamatan Bajawa, guru-guru penjas dan siswa/i. Jenis penelitian ini merupakan penelitian deskriptif kualitatif dengan pendekatan naturalistik. Teknik pengumpulan data yang digunakan yakni berupa observasi, wawancara mendalam dan dokumen pencatatan. Teknik validitas yang digunakan adalah trianggulasi. Teknik analisis data yang digunakan adalah analisis model interaktif melalui tiga komponen yaitu reduksi data, sajian data, dan penarikan kesimpulan atau verifikasi. Hasil dari penelitian ini adalah Pemerintah daerah dalam hal ini oleh pemerintah kecamatan Bajawa melalui dinas terkait telah membuat kebijakan policy as spesific proposals berupa usulan-usulan ke atas bottonup dengan mekanisme laporan dari sekolah melalui unit pelaksana teknis dinas kecamatan selanjutnya ke dinas pendidikan dan ke pemerintah daerah maupun pemerintah pusat dibahas dan dianggarkan untuk diberi bantuan sarana dan prasarana olahraga. Bantuan tersebut berupa barang maupun berupa dana yang nantinya dibelanjakan lewat sekolah melalui dana alokasi khusus, namun untuk beberapa tahun ini mengalami ketiadaan dana tersebut sehingga sekolah hanya bersandar dari dana bantuan operasional sekolah yang cukup terbatas di dalam pengelolaannya. Ketersediaan sarana dan prasarana olahraga pendidikan di SMP Negeri di Kecamatan Bajawa telah memenuhi standar minimum berdasarkan standar sarana dan prasarana olahraga di SMP/MTs meliputi peralatan pendidikan, media dan sumber belajar,tempat berolahraga serta tempat bermain dan rekreasi yang diperlukan untuk proses pembelajaran yang teratur dan berkelanjutan. Ketercukupan sarana dan prasarana olahraga pendidikan di SMP Negeri se-kecamatan Bajawa secara umum telah memiliki prasarana yang baik (lapangan dan area berolahraga),akan tetapi untuk sarana seperti alat-alat olahraga masih kurang yang berbanding terbalik dengan rasio jumlah siswa di setiap kelasnya. Rata-rata siswa perkelas untuk rombel kelas VII-IX jumlahnya sebanyak 35-40 siswa, sementara sarana dan fasilitas olahraga jumlahnya sebanyak 10 buah untuk tiap set alat tersebut tidak termasuk dengan yang telah rusak atau tidak layak pakai.
\end{abstract}

Kata kunci : kebijakan,ketersediaan, ketercukupan, sarana dan prasarana

\begin{abstract}
This study aims to describe government policies regarding the provision of infrastructure and education for educational facilities in the Middle school in Bajawa Sub-district in the fields of the aspects, availability of adequate facilities. This research
\end{abstract}


was conducted at the Public Middle School in the Bajawa Sub-District area. The subjects in this study were the head of the SMP / MTs field, the head of the state junior high school in Bajawa sub-district, the teachers who were students.

The type of research is qualitative descriptive research with naturalistic approaches. The technique of data collection used is similar observation, interview in and document records. The validity technique used is the estimation. Technical analysis of the data is used instead of interactive analysis models through the number of components of data reduction, data presentation, and conclusions or verification. The results of this study are that the local government in this case by the Bajawa subdistrict government through the relevant agencies has made policy policy specifically proposals to be up-and-up proposals with the mechanism of reporting from schools through the subsequent sub-district technical implementation unit to the education office and to the local government and the central government is discussed and budgeted for assistance with sports facilities and infrastructure. The assistance is in the form of goods or in the form of funds which will be spent through schools through special allocation funds, but for several years this has been lacking of funds so that the school only relies on school operational assistance funds which are quite limited in its management. The availability of educational sports facilities and infrastructure in the Public Middle School in Bajawa sub-district has met the minimum standards based on the standards of sports facilities and infrastructure in SMP / MTs including educational equipment, media and learning resources, a place to exercise and a playground and recreation needed for a regular and continuous learning process. The adequacy of educational sports facilities and infrastructure in Bajawa sub-district in general has good infrastructure (field and sports area), but facilities such as sports equipment are still lacking which is inversely proportional to the ratio of the number of students in each class. The average class of students for the VII-IX class is around 35-40 students, while the sports facilities and facilities are 10 for each set, not including those that have been damaged or not suitable for use.

Keywords: policy, availability, adequacy, facilities and infrastructure

\section{PENDAHULUAN}

\begin{tabular}{lcr}
\multicolumn{2}{c}{ Pembangunan } & manusia \\
dalam bidang & pendidikan \\
merupakan & salah satu & upaya \\
peningkatan & kualitas & hidup \\
masyarakat & Indonesia & yang \\
ditempuh & melalui & upaya \\
peningkatan & kesehatan jasmani \\
dan rohani, sikap disiplin dan & dan \\
sportifitas serta pengembangan \\
prestasi untukmembangkitkan rasa \\
kebangsaan nasional. Berbagai \\
kemajuan pembangunan di bidang \\
pendidikan dan keolahragaan akan \\
bermuara pada meningkatnya
\end{tabular}

budaya serta prestasi olahraga pelajar itu sendiri. Melalui UU RI No. 20 tahun 2003 tentang sistem pendidikan nasional telah menggariskan bahwa sistem pendidikan nasional merupakan keseluruhan komponen pendidikan yang saling terkait secara terpadu untuk mencapai tujuan pendidikan nasional. Pendidikan yang sehat sejatinya merupakan pendidikan yang mampu memahami zamannya dan selalu berusaha memenuhi tuntutan-tuntutannya. Oleh karena itu, pendidikan harus 
selalu bersifat dinamis. Hanya dengan terus bertransformasi dan bereformasi, pendidikan akan menemukan relevansinya dengan situasi zaman yang sedang dan akan terus berubah. Natal (2017:269).

Pendidikan Jasmani, Olahraga, dan Kesehatan itu sendiri merupakan bagian integral dari pendidikan secara keseluruhan yang bertujuan untuk mengembangkan aspek kebugaran jasmani, keterampilan gerak, keterampilan berfikir kritis, keterampilan sosial, penalaran, stabilitas emosional, tindakan moral,aspek pola hidup sehat dan pengenalan lingkungan bersih melalui aktifitas jasmani, olahraga, dan kesehatan terpilih yang direncanakan secara sistematis dalam rangka mencapai tujuan pendidikan Nasional (Depdiknas,2008:194). Melalui pendidikan jasmani dan olahraga disekolah yang berjalan dengan sistematis, kualitas sumber daya manusia dapat diarahkan pada peningkatan pengendalian diri, tanggung jawab, disiplin, sportivitas yang pada akhirnya dapat memperoleh prestasi olahraga yang dapat membangkitkan kebanggaan nasional. Keberhasilan belajar mengajar pendidikan jasmani,olahraga dankesehatan di sekolah seperti yang diharapkan, tentunya ditunjang pula oleh banyak faktor, baik faktor intern dan faktor ekstern. Faktor internal antara lain tenaga pendidik, peserta didik dan sarana prasarana,sedangkan faktor eksternal meliputi lingkungan masyarakat dan dukungan keluarga. Kecamatan Bajawa merupak salah satu kecamatan besar yang ada di kabupaten Ngada merupakan salah satu kabupaten otonomi di Provinsi Nusa Tenggara Timur yang memiliki kewenangan dalam proses pelaksanaan pendidikan jasmani dan olahraga di jenjang pendidikan menengah pertama (SMP). Hal ini tentunya menjadi salah satu prioritas dalam mengkaji serta serta meningkatkan kualitas pembelajaran penjas dan olahraga dimaksud melalui penyediaan sarana dan prasarana yang representatif. Pemerintah pusat melalui Peraturan Pemerintah No. 19 Tahun 2005 tentang Standar Nasional Pendidikan yang menyangkut standar sarana dan prasarana pendidikan nasional pada Bab VII Pasal 42 dengan tegas disebutkan bahwa;

1) Setiap satuan pendidikan wajib memiliki sarana yang meliputi perabot, peralatan pendidikan,media pendidikan, buku dan sumber belajarlainnya, bahan habis pakai, serta perlengkapan lainyang diperlukan untuk menunjang 


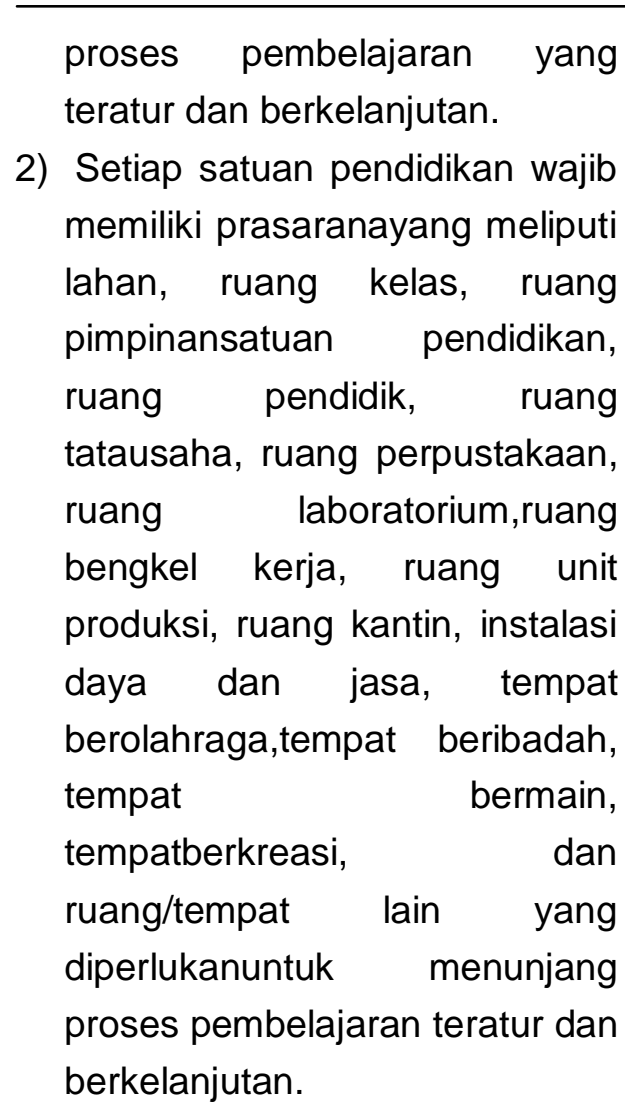

Dari acuan tersebut di atas maka sudah tentu menjadi sebuah arahan bagi pemerintah kota /kabupaten serta kecamatan untuk mampu memfasilitasi, bahkan menyediakan sarana dan prasarana olahraga pendidikan yang layakdemi mewujudkan kelancaran suatu kegiatan belajar mengajar demi terciptanya suatu kegiatan belajar mengajar yang optimal. Hal tersebut berlaku untuk semua bidang studi, termasuk bidang studi pendidikan jasmani, olahraga, dan kesehatan di SD, SMP, SMA, SMK, dan MA.

\section{Hakikat Olahraga}

Olahraga merupakan bagian yang tidak terpisahkan dari kehidupan manusia, yang tercermin melalui sebuah aktivitas gerak manusia yang lahir secara hakiki. Partisipasi kegiatan olahraga muncul dari beberapa kalangan dan datang dari semua lapisan masyarakat. Mulai dari yang tua hingga yang anak-anak, dari golongan orang yang mapan maupun yang tidak mapan, dan tidak membatasi dari jenis kelamin laki-laki maupun perempuan dalam aktivitasnya. Aktivitas olahraga yang digandrungi juga beragam diantaranya untuk alasan kesehatan, kebugaran, maupun dengan alasan lain seperti membentuk karakter positif dan proses bersosialisasi diri di lingkungan masyarakat. Khusus di perkotaan sendiri kegiatan berolahraga menjadi sangat urgen dengan melihat kenyataan bahwa tingkat kesibukan dan aktifitas masyarakat yang sangat padat oleh karena beban kerja yang sangat tinggi serta berbagai tuntutan dunia pekerjaan yang terus mengalami perkembangan, sehingga dirasa perlu untuk menyegarkan pikiran, berekreasi dan bermain melalui aktivitas olahraga tersebut.

Sejatinya bahwa aktivitas olahraga merupakan ekspresi jiwa manusia yang timbul dari dalam diri tanpa ada paksaan dari orang lain sebagai ungkapan untuk mengaktualisasikan dirinya dalam 
tatanan hidup bermasyarakat, berbangsa dan bernegara.

Pada hakekatnya aktivitas olahraga merupakan menu yang menghadirkan kegairahan tersendiri bagi para penikmatnya. Olahraga belakangan telah berubah menjadi sebuah life style yang kian merasuk dan menjadi kebutuhan utama bagi para penggilanya. Sebagaimana sesuai dengan semboyan Yunani Kuno yang berbunyi: Orandum est ut sit, men sana in corpore sano yang dapat diartikan "semoga hendaknya di dalam badan/tubuh/raga yang kuat bersemayam jiwa yang sehat". Sehingga aktivitas olahraga di pandang penting dan berguna bagi kesehatan setiap manusia yang sering melakukan kegiatan olahraga serta memiliki kesehatan rohani dan jasmani yang lebih baik di banding manusia yang jarang atau tidak pernah melakukan kegiatan olahraga. Hal ini senada pula yang diungkapkan oleh Rusli Lutan (2013) bahwa "Olahraga adalah proses sistematik yang berupa segala kegiatan atau usaha yang dapat mendorong, membangkitkan, mengembangkan dan membina potensi-potensi jasmaniah dan rohaniah seseorang sebagai perorangan atau anggota masyarakat dalam bentuk permainan, perlombaan, pertandingan dan kegiatan jasmani yang intensif untuk memperoleh rekreasi, kemenangan dan prestasi puncak dalam rangka pembentukan manusia Indonesia seutuhnya yang berkualitas berdasarkan Pancasila, yang di dalamnya mengandung aspekaspek yang berkaitan dengan tujuan, perjuangan, kerjasama, persaingan, komunikasi dan integrasi, kekuatan fisik dan daya tahan mental, kebersamaan, sikap responsif, pengambilan keputusan, ekspresi diri, nilai kejujuran dan sportifitas".

\section{Ruang Lingkup Olahraga}

Olahraga merupakan cerminan perilaku gerak yang berlangsung pada manusia. Perilaku gerak yang dilakukan memerlukan hubungan koordinasi yang amat kompleks, cepat dan halus dari fungsi neurofisiologisanatomis yang menyatu dengan fungsi psikologis dalam hubungan fungsional yang amat teratur, sesuai dengan ciri-ciri biologis pada manusia. Tanpa disadari aktivitas gerak yang dilakukan manusia sehari-hari merupakan bagian dari olahraga, yang merupakan hasil kerja dari seluruh sistem yang sesuai dan menyatu antara jiwa dan raga, bodyand mind, yang tertuang lewat aktivitas fisik. Manusia bergerak (man in motion) bukan pula hanya disebabkan oleh adanya dorongan 
secara biologis, melainkan juga oleh faktor kejiwaan. Hal itu berarti ketika seseorang melakukan aktivitas gerak dalam berolahraga, ia mengalami peristiwa fisik dan psikis yang saling berkaitan sehingga dapat disimpulkan pengaruh olahraga sangatlah besar terhadap perkembangan psikis yang saling berkaitan erat.

Olahraga sendiri pada dasarnya bersifat netral, namun manusia yang kemudian mengelola kegiatan serta memberi arti bagi kegiatan tersebut. Karena itu di Indonesia sesuai dengan fungsi dan tujuannya kita mengenal beberapa bentuk kegiatan olahraga, seperti olahraga pendidikan, olahraga rekreasi, olahraga kesehatan dan juga olahraga prestasi. Hal ini yang menjadikan olahraga merupakan salah satu tujuan dan aset dari pembangunan manusia keolahragaan.

Senada dengan hal tersebut di atas, menurut Undang-Undang Sistem Keolahragaan Nasional (UUSKN), Nomor 3 Tahun 2005 Bab VI pasal 17 yang menyebutkan "ruang lingkup olahraga meliputi kegiatan : a) olahraga pendidikan, b) olahraga rekreasi, dan c) olahraga prestasi.

\section{Olahraga Pendidikan}

Olahraga pendidikan pada dasarnya bertujuan untuk mendidik. Dalam konteks olahraga pendidikan ini merupakan dasar bagi pembangunan olahraga suatu bangsa. Basis pembinaanya dimulai dan berakar pada lingkungan keluarga, pendidikan formal, di lingkungan persekolahan, dan masyarakat secara luas. Hal yang mendasar ini setidaknya dapat mampu menciptakan iklim kecintaan akan kegiatan olahraga sejak awal lewat pengenalan-pengenalan cabangcabang olahraga kepada anak didik.

Olahraga pendidikan sering juga disebut pendidikan jasmani dan olahraga yang dilaksanakan sebagai bagian proses pendidikan yang teratur dan berkelanjutan untuk memperoleh pengetahuan, kepribadian, keterampilan, kesehatan, dan kebugaran jasmani dijumpai pada sekolah-sekolah. Dalam Undang-Undang Sistem Keolahragaan Nasional, Nomor 3 Tahun 2005 Bab VI pasal 18 ayat 3 berbunyi "olahraga pendidikan dimulai pada usia dini". Olahraga pada anak usia dini memiliki karakteristik yang khas, baik secara fisik, psikis, sosial, moral dan sebagainya. Hal tersebut di atas jelas menggambarkan bahwa pondasi terciptanya atlet yang akan berprestasi terletak pada pembinaan atlet usia dini yang berada pada lingkungan keluarga, sekolah (formal dan non formal), maupun pada klub-klub di 


lingkungan masyarakat.
Pemerintah Indonesia sendiri telah
mengeluarkan kebijakan untuk
meningkatkan kegiatan olahraga
serta meningkatkan prestasi
olahraga harus dimulai dari
sekolah dasar (SD). Hal ini senada
dengan yang diungkapkan oleh
Robinson Ke Rihi (2000:26)
sebagai berikut : $\quad$ "Pelajar
merupakan gudang bibit
keolahragaan Nasional yang tidak
akan habis-habisnya apabila
program olahraga di sekolah
secara keseluruhan dapat
dilaksanakan sebaik-baiknya".
Oleh karena itu, melalui kegiatan
pendidikan jasmani dan olahraga
sekolah yang baik dan bermutu,
akan diperoleh hasil pembangunan
generasi muda mendatang yang
diharapkan selain cerdas dan
terampil adalah juga unggul dalam
prestasi, kompetitif, sehat dan
bugar serta bermartabat dengan
mengoptimalkan pembinaan
olahraga di sekolah sebagai
kegiatan ektrakurikuler tentunya.

\section{Sarana dan Prasarana Olahraga Pendidikan}

Sarana dan prasarana olahraga pendidikan merupakan sesuatu yang tidak bisa terlepas satu sama lain dalam hal pendidikan. Dimana antara keduanya terdapat suatu keterkaitan yang sama. Sarana adalah sesuatu yang dapat digunakan dan dimanfatkan dalam pelaksanaan kegiatan olahraga atau pendidikan jasmani. Sedangkan prasarana adalah sesuatu yang mempermudah atau memperlancar tugas dan memiliki sifat yang relatif permanen (Soepartono, 2004: 5-6).

Bertolak dari pengertian sarana olahraga di atas maka,sarana dapat dibedakan menjadi dua kelompok yaitu:

a. Peralatan (apparatus), ialah sesuatu yang digunakan, contoh: peti loncat, palang tunggal, palang sejajar, gelang-gelang, gawang lompat, dll.

b. Perlengkapan (device), yaitu:

1) Sesuatu yang melengkapi kebutuhan prasarana, misalnya: net, bendera untuk tanda, garisbatas, dan lain-lain.

2) Sesuatu yang dapat dimainkan atau dimanipulasi dengan tangan atau kaki, misalnya: bola, raket, pemukul, dan lain-lain.

Berdasarkan pengertian prasarana olahraga diatas, dapat disebutkan beberapa contoh prasarana olahraga meliputi: lapangan bola basket, lapangan tenis, gedung olahraga, stadion sepakbola, stadion atletik, dan lainlain. Gedung olahraga merupakan prasarana yang berfungsi serba 
guna untuk pertandingan beberapa cabang olahraga, misalnya: pertandingan bola voli, pertandingan bulutangkis, dan lainlain.

Menurut Soepartono (2000:5) sarana pendidikan jasmani. adalah segala sesuatu yang dapat dipakai sebagai alat dalam mencapi maksud dan tujuan, sedangkan prasarana adalah segala sesuatu yang merupakan penunjang utama terselenggaranya suatu proses.Sedangkan menurut Agus S. Suryobroto (2004: 4), menyatakan bahwa prasarana atau perkakas adalah sesuatu yang diperlukan dalam pembelajaran pendidikan jasmani. Mudah dipindah tetapi berat atau sulit diangkat. Prasarana antara lain adalah matras, peti, meja, tenis meja, dll. Perkakas ini idealnya tidakdipindah-pindahkan, agar tidak mudah rusak, kecuali kalau memang tempatnya terbatas sehingga harus selalu bongkar pasang. Lebih lanjut menurut Agus S. Suryobroto (2004: 4), prasarana atau fasilitas adalahsegala sesuatu yang diperlukan dalam pembelajaran penjas, bersifat permanen atau tidak dapat dipindah-pindahkan. Fasilitas antara lain:lapangan (sepakbola, bolavoli, bola basket, kasti, tenis lapangan). Fasilitas harus memenuhi standar minimal untuk pembelajaran, antara lain ukuran sesuai dengan kebutuhan, bersih, terang, pergantian udara lancar, dan tidak membahayakan penggunaannya.

\section{Penyediaan Sarana dan Prasarana Olahraga}

Sarana dan prasarana merupakan suatu hal yang terpenting dalam kegiatan proses belajar mengajar pendidikan jasmani dan kesehatan disetiap sekolah, baik itu ditingkat dasar maupun sekolah tingkat tinggi. Keberadaan dari sarana dan prasarana tidak kalah penting dengan aspek-aspek pengajaran lainnya. Dalam praktek pengajaran sering dijumpai bagaimana seorang guru sangat pandai dalam menyampaikan suatu materi kepada siswanya tetapi tidak didukung dengan sarana dan prasarana yang memadahi, maka mustahil hal tersebut dapat berhasil sesuai dengan apa yang diharapkan.

Menurut Agus S. Suryobroto (2004: 19), dalam hal pengadaan sarana dan prasarana pendidikan jasmani ada dua hal yaitu membeli dan membuat,jika membeli maka perlunya persyaratan-persyaratan tertentu antara lain:mudah didapat, perawatan mudah, harganya tidak terlalu mahal, menarik,dan lain lain. Agar sarana dan prasarana pendidikan jasmani dapat digunakan dengan layak dan awet, 
maka sangat perlunya perawatan yang baik dan benar. Tidak semua sarana dan prasarana perawatannya sama,tergantung dari bahan dan jenisnya, sebagai contoh: perawatan antar aperkakas yang terbuat dari kayu dan besi perawatannya berbeda. Pada intinya sarana adalah merupakan salah satu kebutuhan pokok yang harus terpenuhi yang mudah dipindah atau dibawa dalam pembelajaranpendidikan jasmani antara lain: bola, pemukul, tongkat, balok, bed,shuttlecock, sedangkan prasarana adalah segala seauatu yang diperlukan dalam pembelajaran pendidikan jasmani, mudah dipindah tetapi berat atausulit antara lain: matras, peti lompat, palang tunggal, palang sejajar, palang bertingkat, meja ping pong.

\section{Kebijakan Pemerintah}

Dalam Kamus Besar Bahasa Indonesia, kebijakan diartikan sebagai rangkaian konsep dan asas yang menjadi garis besar dan dasar rencana dalampelaksanaan suatu pekerjaan, kepemimpinan, dan cara bertindak (tentangpemerintahan, organisasi, dsb); pernyataan cita-cita, tujuan, prinsip dangaris pedoman untuk manajemen dalam usaha mencapai sasaran.
Berdasarkan pendapat tersebut di atas maka dapat disimpulkan bahwa kebijakan adalah tindakantindakan atau kegiatan yangsengaja dilakukan atau tidak dilakukan oleh seseorang, suatu kelompokatau pemerintah yang di dalamnya terdapat unsur keputusan berupa upaya pemilihan diantara berbagai alternatif yang ada guna mencapai maksud dan tujuan tertentu. Dengan demikian pemerintah dalam menjalankan roda kepemerintahanmya sudah tentu memiliki kebijakan-kebijakan strategis

yang mana dapat membantu kinerja serta mendorong perubahan serta arah pembagunan daerahnya. Salah satu yakni menyangkut dengan layanan serta kualitas serta ketersediaan sarana dan prasana olahraga pendidikan di sekolah menegah pertama (SMP).

\section{Bentuk-Bentuk Kebijakan Publik}

Brian W.Hogwood dan Lewis

A. Gunn1986 (dalam Wahab 2011 : 16), mengelompokkan kebijakan ke dalam sepuluh macam yaitu: sebagai Sebuah Label atau 1)Policy as a Label for a Feld of Activity (Kebijakan Merk bagi Suatu Bidang Kegiatan Pemerintah). 2) Policy as an Expression of General Purpose or Desired State of Affairs (Kebijakan sebagai Suatu Pernyataan Mengenai Tujuan 


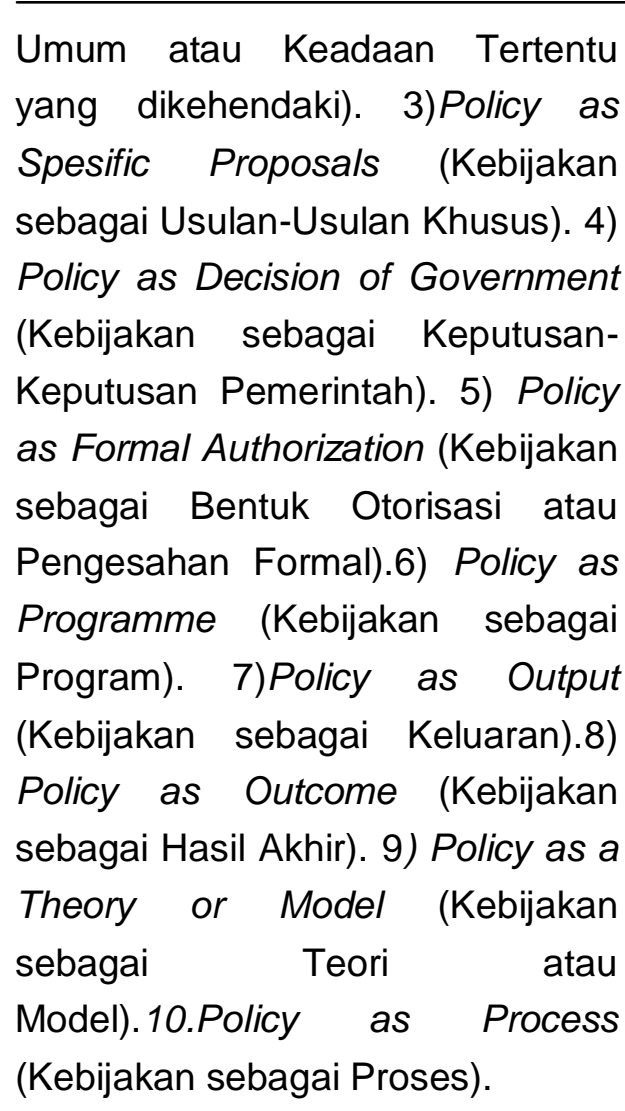

\section{METODE PENELITIAN}

Penelitian ini bertujuan untuk mendeskripsikan kebijakan pemerintah tentang penyediaan sarana dan prasarana olahraga pendidikan di SMP se-Kecamatan Bajawa yang di tinjau dari aspek, ketersediaan serta ketercukupan. Penelitian ini dilakukan di SMP Negeri di wilayah Kecamatan Bajawa. Jenis penelitian ini adalah penelitian kualitatif deskriptif dengan pendekatan kualitatif naturalistik. Subjek dalam penelitian ini adalah kepala bidang SMP/MTs, kepala SMP negeri di Kecamatan Bajawa, guru-guru penjas dan siswa/i. Teknik pengumpulan data yang digunakan

\section{kesimpulan atau verifikasi. \\ HASIL PENELITIAN DAN PEMBAHASAN}

yakni berupa observasi, wawancara mendalam dan dokumen pencatatan. Teknik validitas yang digunakan adalah trianggulasi. Teknik analisis data yang digunakan adalah analisis model interaktif melalui tiga komponen yaitu reduksi data, sajian data, dan penarikan

Kebijakan merupakan produk atau usaha dalam rangka mencapai tujuan tertentu. Kebijakan pemerintah tentang penyediaan sarana dan prasarana olahraga pendidikan di SMP Negeri se-Kecamatan Bajawa tentunya dibuat didasarkan pada masalah yang sedang dihadapi yang disesuaikan dengan kondisi keadaan daerah tersebut. Masalah yang terjadi sebagai akibat dari dibuatnya sebuah kebijakan tentunya bervariasi,sehingga melahirkan adanya sebuah kebjakan publik. Pemerintah daerah dalam hal ini oleh pemerintah kecamatan Bajawa melalui dinas terkait telah membuat kebijakan policy as spesific proposals berupa usulan-usulan ke atas botton-up dengan mekanisme laporan dari sekolah melalui unit pelaksana teknis dinas kecamatan selanjutnya ke dinas pendidikan dan ke pemerintah daerah maupun 
pemerintah pusat dibahas dan dianggarkan untuk diberi bantuan sarana dan prasarana olahraga. Bantuan tersebut berupa barang maupun berupa dana yang nantinya dibelanjakan lewat sekolah melalui dana alokasi khusus (DAK), namun untuk beberapa tahun ini mengalami ketiadaan dana tersebut sehingga sekolah hanya bersandar dari dana bantuan operasional sekolah (BOS) yang cukup terbatas di dalam pengelolaannya. Penyediaan fasilitas sarana dan prasarana olahraga merupakan salah satu bentuk kebijakan publik yang mana telah diamanatkan dalam Undang-Undang Sistem Keolahragaan Nasional Nomor 3 Tahun 2005 kepada pemerintah daerah. Dengan demikian dengan disahkannya Undang-Undang No. 22 Tahun 1999 tentang Pemerintahan Daerah (yang kemudian direvisi pada tahun 2004) serta diimplementasikan sejak Januari 2001, maka beberapa kewenangan daerah dilaksanakan oleh birokrasi pemerintah daerah (PEMDA). Mulai saat itulah Pemda mempunyai kewenangan yang luar biasa untuk merencanakan, merumuskan,melaksanakan, serta mengevaluasi kebijakan-kebijakan yang sesuai dengan keperluan dan tuntutan masyarakat setempat (Agustino, 2011 : 69). Pemerintah dalam hal ini perlu memikirkan upaya lain dalam rangka peningkatan serta pemerataan sarana dan prasarana olahraga di sekolah tersebut sebagai bentuk tanggung jawab terhadap peningkatan kualitas layanan pendidikan di daerah Kecamatan Bajawa yang menjadi miniatur pertumbuhan sumber daya manusia di kabapaten Ngada.

Ketersediaan sarana dan prasarana olahraga menjadi hal yang penting di dalam penyelenggaraan kegiatan pembelajaran di sekolah, dengan kata lain bahwa dengan tersedianya jumlah sarana prasarana olahraga pendidikan secara kualitas maupun kuantitas akan mampu membantu guru di dalam proses pembelajaran dimaksud. Semakin tinggi jenjang sekolah semakin luas dan semakin banyak jumlah sarana dan prasarana yang harus disediakan oleh sekolah tentunya. Seiring dengan adanya perubahan pada pola pemerintahan, yakni dengan diberlakukannya otonomi daerah yang berdampak kepada otonomi pendidikan, maka pola manajemen sekolah yang semula terpusat, kini diotomonikan ke sekolah termasuk di dalamnya berkaitan dengan penyediaan sarana dan prasarana tentunya. Sekolah di tuntut harus memiliki kemandirian dalam mengatur dan mengurus 
kepentingan sekolah menurut
kebutuhan dan kemampuan sendiri
dan tetap mengacu pada peraturan
yang berlaku. Dari hasil temuan di
lapangan, peneliti menemukan
bahwa hampir di setiap SMP
Negeri di wilayah Kecamatan
Bajawa telah tersedia atau memiliki
segala sarana dan prasarana
olahraga berdasarkan standar
minimal sarana dan prasarana
olahraga di SMP/MTs yang terdiri
atas peralatan bola voli 1 set/sekolah minimum 6 bola, peralatan bola sepak 1 set/sekolah minimum 6 bola, peralatan bola basket 1 set/sekolah minimum 6 bola, peralatan senam 1 set/sekolah minimum (matras, peti loncat, tali loncat, simpai, bola platik, tongkat, palang tunggal, gelang), peralatan atletik 1 set/sekolah minimum lembing, cakram, peluru, tongkat estafet dan bak loncat. Hasil penelusuran lebih lanjut peneliti menemukan pembiayaan pengadaan segala sarana dan prasarana tersebut berasal dari dana DAK serta dana BOS yang segala proses pengadaan dilakukan bertahap disesuaikan dengan dana yang diperoleh sekolah tiap tahunnya. Agar sarana dan prasarana olahraga pendidikan yang dibutuhkan sekolah berfungsi optimal dalam mendukung kegiatan pembelajaran di sekolah maka hal yang masih harus

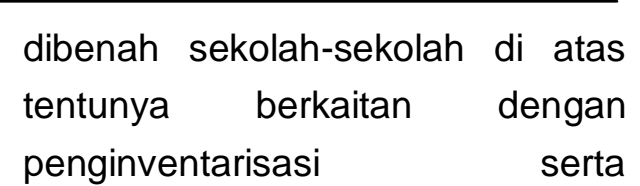

penyimpanan sarana-sarana tersebut ketika selesasai digunakan atau dipakai sehingga mampu meminimalisir dan mencegah dari kerusakan dan kehilangan sarana tersebut.

Ketercukupan semua fasilitas sarana dan prasarana olahraga pendidikan di sekolah melalui aktifitas pendidikan jasmani olahraga dan kesehatan merupakan salah satu faktor penentu kelancaran dari proses belajar dan mengajar tentunya. Dari hasil temuan di lapangan SMP se-Kecamatan Bajawa sebagian besar telah mempunyai prasarana yang baik yakni lapangan dan area berolahraga, akan tetapi untuk sarana seperti alat-alat olahraga masih ada yang kurang berbanding terbalik dengan rasio jumlah siswa di setiap kelasnya. Rata-rata siswa perkelas untuk rombel kelas VII-IX jumlahnya sebanyak 35-40 siswa, sementara sarana dan fasilitas olahraga jumlahnya sebanyak 10 buah untuk tiap set alat tersebut tidak termasuk dengan yang telah rusak atau tidak layak pakai. Hal ini dapat berdampak pada kurang efektifnya kegiatan belajar mengajar di sekolah. Ada beberapa alternatif yang bisa dijadikan cara oleh SMP-SMP Negeri di wilayah kecamatan 


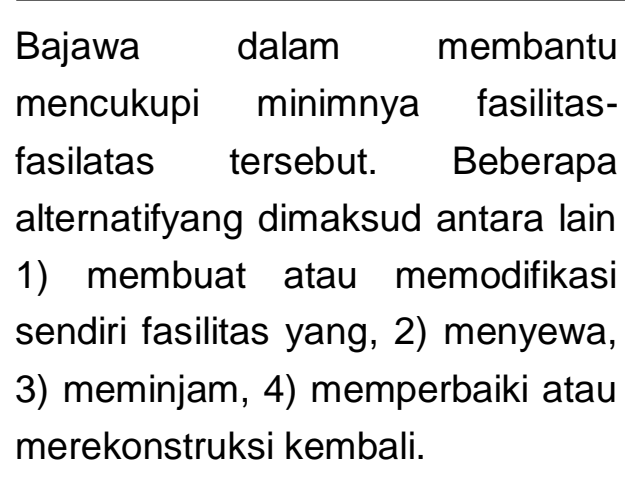

\section{PENUTUP}

Berdasarkan pembahasan yang telah di uraikan mengenai kebijakan pemerintah tentang penyediaan sarana dan prasarana olahraga pendidikan di SMP Negeri di Kecamatan Bajawa yang di tinjau dari aspek ketersediaan serta ketercukupan di maka dapat ditarik kesimpulan antara lain :

1) Pemerintah daerah dalam hal ini oleh pemerintah kecamatan Bajawa melalui dinas terkait telah membuat kebijakan policy as spesific proposals berupa usulanusulan ke atas botton-up dengan mekanisme laporan dari sekolah melalui UPTD dinas kecamatan selanjutnya ke dinas pendidikan dan ke pemerintah daerah maupun pemerintah pusat dibahas dan dianggarkan. Bantuan tersebut berupa barang maupun berupa dana yang nantinya dibelanjakan lewat sekolah melalui dana DAK (dana alokasi khusus).
Akan tetapi untuk beberapa
tahun ini mengalami
ketiadaan dana tersebut
sehingga sekolah hanya
bersandar dari dana BOS
(bantuan
sekolah) operasional
terbatas yang cukup pengelolaannya, sehingga membutuhkan adanya kebijakan lain bahkan sumber dana lain dari pemerintah daerah untuk mengatasi persoalan tersebut.

2) Ketersediaan sarana dan prasarana olahraga pendidikan di SMP Negeri di Kecamatan Bajawa telah memenuhi standar minimum berdasarkan standar sarana dan prasarana olahraga di SMP/MTs meliputi peralatan pendidikan, media dan sumber belajar, ruang kelas, tempat berolahraga dan tempat bermain dan rekreasi yang diperlukan untuk proses pembelajaran yang teratur dan berkelanjutan. Hal yang masih harus dibenah sekolah-sekolah di atas tentunya berkaitan dengan penginventarisasi serta penyimpanan saranasarana tersebut ketika selesai digunakan atau 


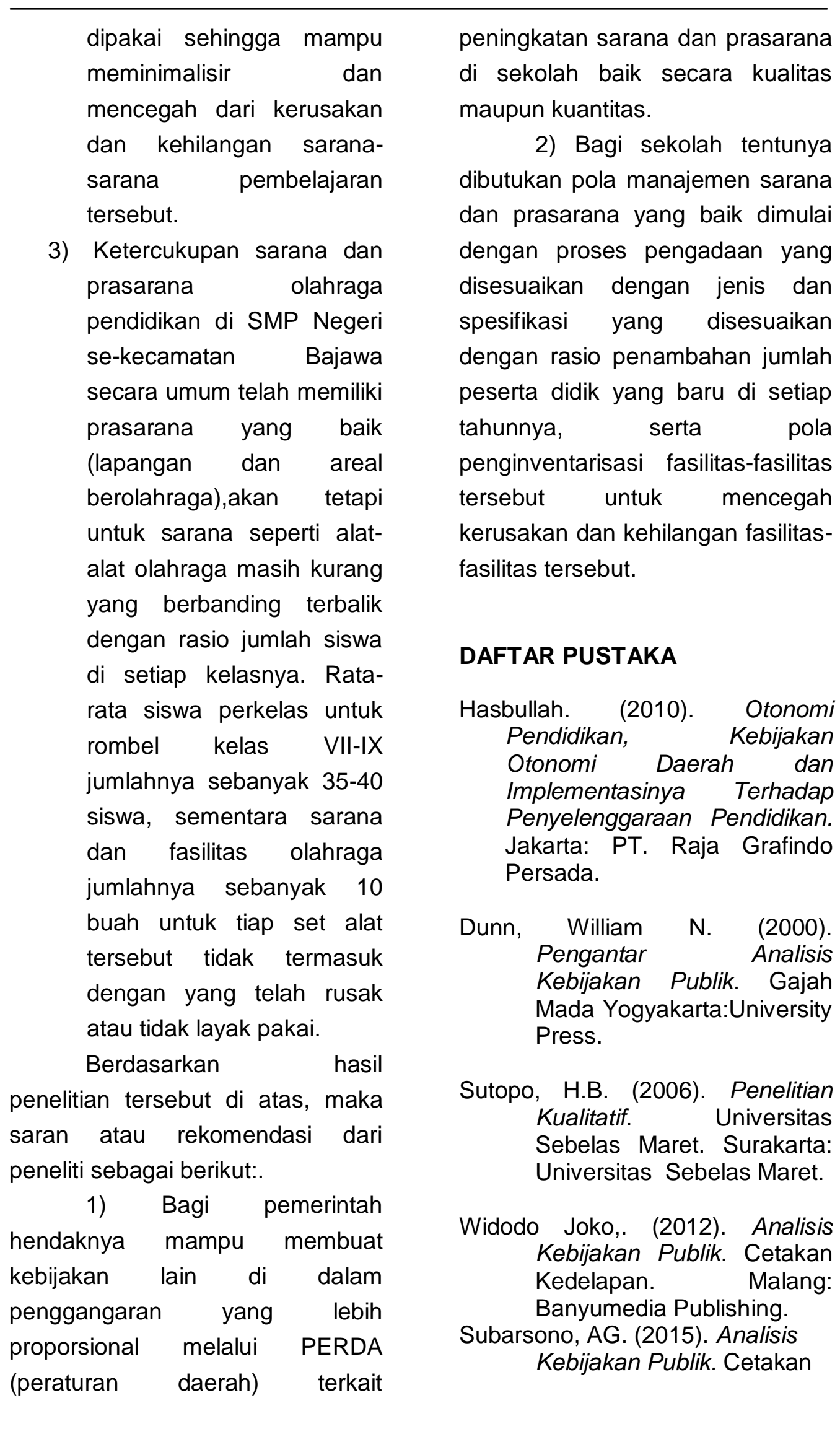


Ketujuh. Yogyakarta : Pustaka Pelajar

Matin, Fuad Nurhattati. (2017). Manajemen Sarana dan Prasarana Pendidikan. Depok : Rajawali Pers.

Ke Rihi, Robinson. 1998. Makalah Pendidikan Olahraga Dataran Timor. UNC. Kupang

Kristiyanto, Agus. 2012. Pembangunan Olahraga, Surakarta : Yuma Pustaka

Lutan, Rusli. 2002. Manusia dan Olahraga. ITB dan FPOK/IKIP Bandung. Bandung

Agus S. Subroto. (2004). Sarana dan Prasarana Pendidikan Jasmani. Yogyakarta : FIK UNY

Natal,Y.R. (2017). Manusia vz Pendidikan. Proceeding Jurnal IImiah Pendidikan Citra Bakti. Ngada
Agustino. (2011). Sisi Gelap Otonomi Daerah:Sisi Gelap Desentralisasi di Indonesia Berbanding Era Sentralisasi. Bandung: Widya Padjadjaran.

Wahab Abdul. (2011). Pengantar Analisis Kebijakan Publik. Malang: UPT. Penerbitan Universitas Muhammadiyah Malang

Soepartono. (2000). Sarana dan Prasarana Olahraga. Jakarta : Depdiknas

Peraturan Pemerintah .No 16 Tahun 2007. Standar Penyelenggaraan Keolahragaan, Jakarta 